\title{
Synthesis, Characterization and Property Studies on a Dinuclear Copper(II) Complex with Dipyridine Derivate and Acetylacetone
}

\author{
Pu Su Zhao, Z Zhi Yan Guo, Jing Sui, Jing Wang, and Fang Fang Jian \\ New Materials \& Function Coordination Chemistry Laboratory, Qingdao University of Science and Technology, \\ Qingdao Shandong 266042, P. R. China. "E-mail: zhaopusu@163.com \\ Received August 10, 2010, Accepted September 30, 2010
}

\begin{abstract}
A dinuclear copper(II) complex of $\left[\mathrm{Cu}_{2}(\text { aceace })_{4}(\right.$ dipyph $\left.)\right]$ [aceace $=$ acetylacetone, dipyph $=1,4-$ di $(4-$ pyridylethene-2-yl-)benzene] has been synthesized and characterized by elemental analysis, IR and X-ray single crystal diffraction. It crystallizes in the monoclinic system, space group $P 21 / c$, with lattice parameters $a=7.9584(16) \AA, b=$ 18.594(4) $\AA, c=15.063(4) \AA, \beta=120.97(2)^{\circ}$ and $M_{r}=807.85\left(\mathrm{C}_{40} \mathrm{H}_{44} \mathrm{Cu}_{2} \mathrm{~N}_{2} \mathrm{O}_{8}\right), Z=2$. Each of the $\mathrm{Cu}^{2+}$ ion adopts a square pyramid geometry and coordinates with four oxygen atoms from two aceace ligands and one nitrogen atom from dipyph bidentate ligand. Magnetic measurement shows that the Weiss constant and Curie constant for the title compound are $-0.22 \mathrm{~K}$ and $0.1154 \mathrm{emu} \cdot \mathrm{K} / \mathrm{mol}$, respectively. Thermal stability data indicate that the title complex undergoes two steps decomposition and the residue is $\mathrm{Cu}_{2} \mathrm{O}_{4}$. In the potential range of $-1.5 \sim 0.8 \mathrm{~V}$, the title complex represents an irreversible electrochemical process.
\end{abstract}

Key Words: Dinuclear Cu complex, Crystal structure, Magnetic property, Thermal stability, Electrochemical property

\section{Introduction}

Construction of supramolecular architectures with interesting physical properties has grown rapidly owing to their potentiality as new functional material. ${ }^{1-4}$ The most efficient and widely used approach for designing such material is the self-assembly of organic ligands and metal ions, and the type/topology of the products generated from this process can be tuned by a judicious choice of the ligands, ${ }^{5-6}$ metal coordination geometry preference, counter ion, ${ }^{6-8}$ solvent, ${ }^{8-9}$ metal to ligand ratio ${ }^{10-11}$ and temperature. ${ }^{12}$ Among these, the choice of organic ligand is one of the important factors. Organic chelating ligands block some coordination sites whereas organic spacers serve to link metal sites and to propagate the structural information expressed in the metal coordination preferences through the extended structure. The properties of the organic spacers, such as solubility, coordination activity, length, geometry and relative orientation of the donor groups play a very important role in dictating polymer framework topology and even in affecting the formation of polymer vs. oligomer $v s$. molecule.

Most commonly used organic spacers for designing the coordination architecture are pyrazine, ${ }^{13-14}$ bridged bidentate bipyridyl ligands ${ }^{15-17}$ and nitrile substituted pyridine ${ }^{18}$ For designing dinuclear metal complex, an unsaturated coordination environment for single coordinated metal and the presence of a bridging atom or ligands are essential. In addition, the reaction conditions appear crucial in designing the dinuclear complexes. ${ }^{19}$ Herein, we report the synthesis, crystal structure and properties of a dinuclear copper(II) complex with a bridged bidentate bipyridyl ligand of 1,4-di(4-pyridylethene-2-yl-)benzene(dipyph), which was synthesized by our group, and the organic chelating ligand of acetylacetone (aceace).

\section{Experimental Section}

All reagents were purchased from commercial sources and used without further purification. Element analyses were performed on a Perkin-Elmer 2400LS elemental analyzer. The melting points were determined on a Yanaco MP-500 melting point apparatus. IR spectra were recorded from 4000 to $400 \mathrm{~cm}^{-1}$ using $\mathrm{KBr}$ pellets on a Nicolet AVATAR360 instrument. ${ }^{1} \mathrm{H}$ NMR spectra were recorded in DMSO at room temperature at $400 \mathrm{MHz}$ on a Bruker instrument. The magnetic susceptibilities were performed on a Quantum Design MPMS-7 SQUID magnetometer. Thermogravimetry (TG) and differential thermal gravimetric (DTG) analysis were carried out on a SDR 2980 simultaneously for the samples of $10 \mathrm{mg}$ at a heating rate of 10 ${ }^{\circ} \mathrm{C} / \mathrm{min}$.

Preparation of $\left[\mathrm{Cu}_{2}\right.$ (aceace) ${ }_{4}$ (dipyph)]. Firstly, according to the methods reported earlier, ${ }^{20-22}$ the bridged bidentate bipyridyl ligand of 1,4-di(4-pyridylethene-2-yl-)benzene(dipyph) was synthesized and synthetic path is showed in Scheme 1. The products of dipyph were yellow powders. Yield $95.1 \%$. mp 282.4 $284.1{ }^{\circ}$ C. Anal. Calcd (\%): C, 84.47; H, 5.67; N, 9.85; Found (\%): C, 84.31; H, 5.5 4; N, 9.98. ${ }^{1}$ H NMR (400 Hz, DMSO) $\delta^{1} 8.044-$ $7.174(\mathrm{~m}, 12 \mathrm{H}), 5.430-5.423$ (d, 2H), 4.159-4.075 (m, 2H); IR $\left(\mathrm{KBr}, \mathrm{cm}^{-1}\right): 3433.61,3024.42,1633.00,1587.53,1412.10$, $1090.25,968.83,829.65,702.13$.

Then, solid dipyph ( $2 \mathrm{mmol}, 0.568 \mathrm{~g}$ ) was dissolved in $50 \mathrm{~mL}$ DMF solvent. Fresh $\mathrm{Cu}(\text { aceace })_{2}(4 \mathrm{mmol}, 1.048 \mathrm{~g})$ was added to this solution with stirring and the resulting solution was heated to refluxing. After $4.5 \mathrm{~h}$, the reaction was stopped and the mix-

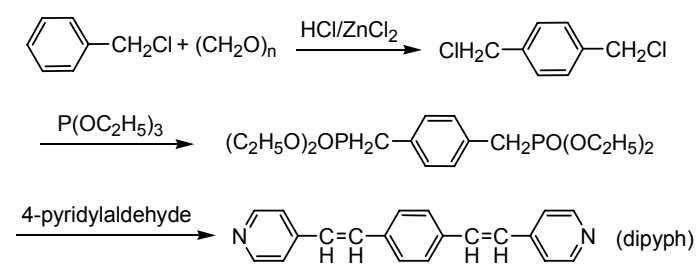

Scheme 1. Synthetic path for the bridged bidentate bipyridyl ligand of dipyph 
ture was cooled to room temperature. The blue solution obtained was filtered and left to evaporate. A week later, the blue crystals of $\left[\mathrm{Cu}_{2}\left(\mathrm{C}_{5} \mathrm{H}_{7} \mathrm{O}_{2}\right)_{4}\left(\mathrm{C}_{20} \mathrm{H}_{16} \mathrm{~N}_{2}\right)\right]$ suitable for X-ray determination were obtained. Anal. Calcd (\%): C, 59.46; H, 5.49; N, 3.47; Found (\%): C, 59.33; H, 5.54; N, 3.66. IR (KBr, cm $\left.{ }^{-1}\right): 3418.66$, 3025.33, 1630.14, 1589.62, 1415.41, 973.72, 822.40, 556.56.

X-ray crystallography. The title complex was glued to a thin glass fiber with epoxy resin and collected on a Enraf-Nonius CAD-4 diffractometer with graphite-monchromated Mo K $\alpha$ radiation $[\lambda=0.71073 \AA, T=293(2) \mathrm{K}]$. The crystallographic collection and refinement parameters for the compound are listed in Table 1 . The empirical absorption correction was based on equivalent reflections, and other possible effects, such as absorption by the glass fiber, were simultaneously corrected. The structure of the complex was solved by direct methods and refined by least squares on $F^{2}$. The hydrogen atom positions were fixed geometrically at calculated distances and allowed to ride on the parent carbon atoms and all non-hydrogen atoms were anisotropically refined. The SMART software was used for collecting frames of data, indexing reflections, and determination of lattice constants; SAINT-PLUS for integration of intensity of reflections and scaling; SADABS for absorption correction; and SHELXTL for space groups and structure determinations, refinements, graphics, and structure reporting. ${ }^{23-25}$

CCDC No. 786020 contains the supplementary crystallographic data for the title complex. These data can be obtained free of charge from The Cambridge Crystallographic Data Centre via www. ccdc.cam.ac.uk/ data_request/cif.

Electrochemical measurement. The cyclic voltammetric (CV) measurements were performed on CHI 660 electrochemical workstation using a conventional three-electrode system, which consisted of a Pt working electrode and $\mathrm{Pt}$ auxiliary electrode,

Table 1. Crystallographic collection and refinement parameters for the title complex

\begin{tabular}{ll}
\hline Empirical formula & $\mathrm{C}_{40} \mathrm{H}_{44} \mathrm{Cu}_{2} \mathrm{~N}_{2} \mathrm{O}_{8}$ \\
\hline Formula weight & 807.85 \\
Crystal color & blue \\
Temperature & $273(2) \mathrm{K}$ \\
Wavelength & $0.71073 \AA$ \\
Crystal system, Space group & Monoclinic, $P 21 / c$ \\
Unit cell dimensions & $a=7.9584(16) \AA$ \\
& $b=18.594(4) \AA, \beta=120.97(2)^{\circ}$ \\
& $c=15.063(4) \AA$ \\
$V$, & $1911.2(8) \AA^{3}$ \\
$Z$, Calculated density & $42,1.404 \mathrm{Mg} / \mathrm{m}^{3}$ \\
Absorption coefficient & $1.166 \mathrm{~mm}^{-1}$ \\
$F(000)$ & 840 \\
Theta range for data collection & 1.92 to $27.05^{\circ}$ \\
Limiting indices & $-10 \leq h \leq 5,-23 \leq k \leq 21,-19 \leq l \leq 18$ \\
Reflections collected/unique & $8900 / 4017\left[R_{\text {int }}=0.0241\right]$ \\
Refinement method & Full-matrix least-squares on $F^{2}$ \\
Data/restraints/parameters & $4017 / 0 / 235$ \\
Goodness-of-fit on $F^{2}$ & 1.099 \\
Final $R$ indices $[I>2 \sigma(I)]$ & $R_{1}=0.0537, w R_{2}=0.1285$ \\
$R$ indices (all data) & $R_{1}=0.0672, w R_{2}=0.1357$ \\
Largest diff. peak and hole & -0.463 and -0.226 e $\AA^{-3}$ \\
&
\end{tabular}

an $\mathrm{Ag} / \mathrm{AgCl}$ reference electrode $(1 \mathrm{M} \mathrm{KCl})$ and a scan rate of $200 \mathrm{mV} / \mathrm{s}$. 0.1 M Tetrabutylammonium perchlorate (TBAP) was used as supporting electrolyte. The concentration of the title complex was $1.0 \times 10^{-3} \mathrm{M}$ in DMF solution. All the potential values are referenced to the $\mathrm{Ag} / \mathrm{AgCl}$ electrode. Current-potential curve was displayed on an IBM computer using model 270 electrochemical analysis software.

\section{Results and Discussion}

Description of crystal structure. The perspective view of the title complex with atomic numbering scheme is showed in Figure 1 and Figure 2 shows the perspective view of the crystal packing in the unit cell. Some selected bond lengths and bond angles are listed in Table 2.

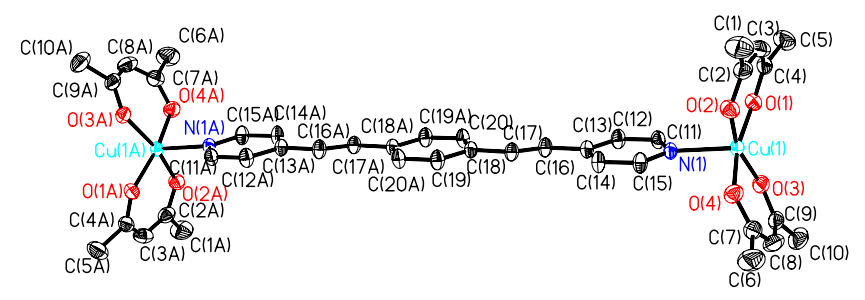

Figure 1. View of the title complex with $30 \%$ probability displacement ellipsoids (Hydrogen atoms are omitted for clarity).

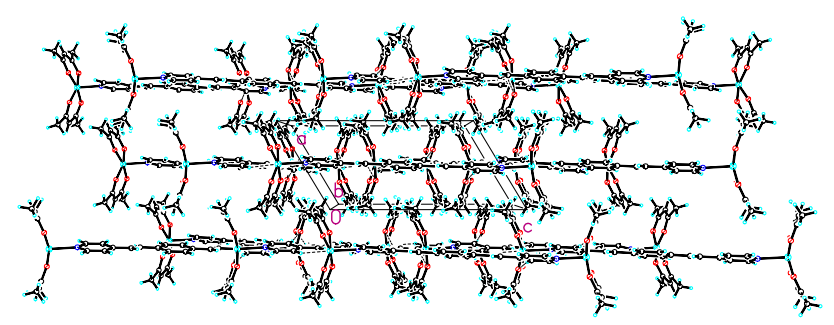

Figure 2. Packing diagram of the unit cell along the $b$-axial for the title complex.

Table 2. Selected bond lengths $(\AA)$ and angles $\left({ }^{\circ}\right)$ for the title complex

\begin{tabular}{cccc}
\hline Bond & $\begin{array}{c}\text { Bond length } \\
(\AA)\end{array}$ & Bond & $\begin{array}{c}\text { Bond length } \\
(\AA)\end{array}$ \\
\hline $\mathrm{Cu}(1)-\mathrm{O}(4)$ & $1.940(3)$ & $\mathrm{Cu}(1)-\mathrm{O}(3)$ & $1.941(2)$ \\
$\mathrm{Cu}(1)-\mathrm{O}(2)$ & $1.941(2)$ & $\mathrm{Cu}(1)-\mathrm{O}(1)$ & $1.948(2)$ \\
$\mathrm{Cu}(1)-\mathrm{N}(1)$ & $2.226(3)$ & $\mathrm{O}(1)-\mathrm{C}(4)$ & $1.275(4)$ \\
$\mathrm{O}(2)-\mathrm{C}(2)$ & $1.271(5)$ & $\mathrm{O}(4)-\mathrm{C}(7)$ & $1.269(5)$ \\
$\mathrm{O}(3)-\mathrm{C}(9)$ & $1.281(5)$ & $\mathrm{N}(1)-\mathrm{C}(11)$ & $1.323(4)$ \\
$\mathrm{C}(11)-\mathrm{C}(12)$ & $1.378(4)$ & $\mathrm{C}(4)-\mathrm{C}(5)$ & $1.506(5)$ \\
$\mathrm{C}(1)-\mathrm{C}(2)$ & $1.518(6)$ & $\mathrm{C}(16)-\mathrm{C}(17)$ & $1.319(4)$ \\
$\mathrm{C}(18)-\mathrm{C}(19)$ & $1.390(4)$ & $\mathrm{C}(18)-\mathrm{C}(20)$ & $1.398(4)$ \\
$\mathrm{Bond}$ angle & $\mathrm{Bond}$ angle $\left({ }^{\circ}\right)$ & $\mathrm{Bond}$ angle & Bond angle $\left(^{\circ}\right)$ \\
$\mathrm{O}(2)-\mathrm{Cu}(1)-\mathrm{O}(1)$ & $91.54(11)$ & $\mathrm{O}(4)-\mathrm{Cu}(1)-\mathrm{O}(2)$ & $85.35(12)$ \\
$\mathrm{O}(4)-\mathrm{Cu}(1)-\mathrm{O}(3)$ & $92.29(12)$ & $\mathrm{O}(4)-\mathrm{Cu}(1)-\mathrm{O}(1)$ & $166.95(11)$ \\
$\mathrm{O}(4)-\mathrm{Cu}(1)-\mathrm{N}(1)$ & $96.58(11)$ & $\mathrm{O}(2)-\mathrm{Cu}(1)-\mathrm{N}(1)$ & $98.76(11)$ \\
$\mathrm{O}(3)-\mathrm{Cu}(1)-\mathrm{N}(1)$ & $98.02(10)$ & $\mathrm{O}(1)-\mathrm{Cu}(1)-\mathrm{N}(1)$ & $96.42(10)$ \\
$\mathrm{O}(2)-\mathrm{C}(2)-\mathrm{C}(3)$ & $124.8(4)$ & $\mathrm{O}(4)-\mathrm{C}(7)-\mathrm{C}(8)$ & $125.1(4)$ \\
$\mathrm{C}(11)-\mathrm{N}(1)-\mathrm{C}(15)$ & $115.7(3)$ & $\mathrm{C}(12)-\mathrm{C}(13)-\mathrm{C}(14)$ & $115.9(3)$ \\
$\mathrm{C}(17)-\mathrm{C}(16)-\mathrm{C}(13)$ & $126.8(3)$ & $\mathrm{C}(19)-\mathrm{C}(18)-\mathrm{C}(20)$ & $116.7(3)$ \\
\hline
\end{tabular}


The structure unit of the title complex contains a pair of independent $\left[\mathrm{Cu}_{2} \text { (aceace }\right)_{4}($ dipyph $\left.)\right]$ molecules. Each of the molecule has an inversion center, which is located at the phenyl ring center. The coordination environments of the two $\mathrm{Cu}^{2+}$ ions are similar and each $\mathrm{Cu}^{2+}$ ion is pentacoordinated with four $\mathrm{O}$ atoms and one $\mathrm{N}$ atom in a distorted square pyramidal geometry, with the bond angles of $\mathrm{O}-\mathrm{Cu}-\mathrm{O}$ being in the range of 85.35(12) to $166.95(11)^{\circ}$ and $\mathrm{O}-\mathrm{Cu}-\mathrm{N}$ bond angles from $96.42(10)$ to 98.76 $(11)^{\circ}$. The basal coordination position are occupied by four $\mathrm{O}$ atoms from two acetylacetone chelating ligands and the apical position is occupied by the $\mathrm{N}$ atom from a pyridyl ring of the bipyph, while the copper(II) atom is located in the center of the pyramid base with the $\mathrm{Cu}(\mathrm{II})$ atom apart from the pyramidal base being 0.251(1) $\AA$. The $\mathrm{Cu}-\mathrm{O}$ distances from 1.941(2) to 1.948 (2) $\AA$ are all longer than those in the similar five-coordinated $\mathrm{Cu}$ complex of $\mu^{2}$-1,2-bis(2-pyridyl)ethene)-bis((trifluoroacetylacetonato-O,O')-copper(II)) [Cu-O 1.926(2) - 1.937(4) $\AA]^{26}$ and corresponding with those in $\left(\mu^{2}-2,5\right.$-bis(2-pyridylethynyl)thiophene)-tetrakis(1,1,1-trifluoroacetylacetonato)di-copper(II) [Cu-O 1.935 (3) - 1.956 (4) $\AA]^{27}$ The $\mathrm{Cu}-\mathrm{N}$ distance of 2.226(3) $\AA$ is shorter than those in above two cited $\mathrm{Cu}$ complexes [Cu-N $2.315 \AA^{26}$ and $2.275 \AA^{27}$ ]. All of the bond lengths and bond angles in the phenyl rings and pyridyl rings are in the normal range. The pyridyl ring along with $\mathrm{C}(16)$ atom define a plane $P 1$ with the biggest deviation being $-0.019 \AA$ for $\mathrm{C}(12)$ atom and phenyl ring with the attached atoms of $\mathrm{C}(17)$ and $\mathrm{C}(17 \mathrm{~A})$ define another plane $P 2$ with the biggest deviation being $0.006 \AA$ for $\mathrm{C}(18)$ and $\mathrm{C}(18 \mathrm{~A})$ atoms. The dihedral angle between above two planes is $1.50(2)^{\circ}$, and the biggest distance from the atoms in $P 1$ to the plane $P 2$ is $0.173(1) \AA$ for atom $\mathrm{C}(14)$, which means that all of the atoms in the bidentate ligand of bipyph are almost coplanar.

In the crystal lattice, there exist some week intermolecular interactions (see Table 3), including $\mathrm{C}-\mathrm{H} \cdots \pi$ and $\mathrm{C}-\mathrm{H} \cdots \mathrm{O}$ interactions, which help to stabilize the molecular structure.

Magnetic property. The magnetic property of the title complex is depicted in Figure 3 with plot of molar magnetic susceptibility $\chi_{\mathrm{m}} v s$ temperature $T$. As a whole, from temperature of $300 \mathrm{~K}$ changing to $2.0 \mathrm{~K}$, the values of molar susceptibility $\chi_{\mathrm{m}}$ do not change evidently. At first, $\chi_{\mathrm{m}}$ changes slowly, and then it increases sharply from $0.00406 \mathrm{emu} / \mathrm{mol}$ at $30.0 \mathrm{~K}$ to 0.0644 $\mathrm{emu} / \mathrm{mol}$ at $2.0 \mathrm{~K}$. Magnetic susceptibility data between $2.0 \mathrm{~K}$ to $300.0 \mathrm{~K}$ obeyed the Curie-Weiss law $\chi_{\mathrm{m}}=C /(T+\theta)$, with Curie constant $C=0.1154 \mathrm{emu} \cdot \mathrm{K} / \mathrm{mol}$ and Weiss constant $\theta=$

Table 3. Some weak intermolecular interactions ${ }^{a}$

\begin{tabular}{cccc}
\hline $\mathrm{D}-\mathrm{H} \cdots \mathrm{A}$ & Symmetry code & $\mathrm{D} \cdots \mathrm{A}(\AA)$ & $\mathrm{D}-\mathrm{H} \cdots \mathrm{A}\left({ }^{\circ}\right)$ \\
\hline $\mathrm{C}(14)-\mathrm{H}(14 \mathrm{~A}) \cdots \mathrm{O}(2)$ & $1-\mathrm{x},-\mathrm{y},-\mathrm{z}$ & 3.3706 & 172.62 \\
$\mathrm{C}(16)-\mathrm{H}(16 \mathrm{~A}) \cdots \mathrm{O}(1)$ & $\mathrm{x}, 1 / 2-\mathrm{y},-1 / 2+\mathrm{z}$ & 3.3318 & 146.69 \\
$\mathrm{C}(16)-\mathrm{H}(16 \mathrm{~A}) \cdots \mathrm{O}(3)$ & $\mathrm{x}, 1 / 2-\mathrm{y},-1 / 2+\mathrm{z}$ & 3.3131 & 136.02 \\
$\mathrm{C}(5)-\mathrm{H}(5 \mathrm{C}) \cdots \mathrm{Cg}(3)$ & $1+\mathrm{x}, 1 / 2-\mathrm{y}, 1 / 2+\mathrm{z}$ & 3.6485 & 141.91 \\
$\mathrm{C}(1)-\mathrm{H}(1 \mathrm{~B}) \cdots \mathrm{Cg}(4)$ & $1+\mathrm{x}, \mathrm{y}, 1+\mathrm{z}$ & 3.6909 & 133.77 \\
$\mathrm{C}(1)-\mathrm{H}(1 \mathrm{~B}) \cdots \mathrm{Cg}(4)$ & $2-\mathrm{x},-\mathrm{y},-\mathrm{z}$ & 3.6909 & 133.77 \\
$\mathrm{C}(8)-\mathrm{H}(8 \mathrm{~A}) \cdots \mathrm{Cg}(3)$ & $-1+\mathrm{x}, \mathrm{y}, \mathrm{z}$ & 4.0504 & 132.90 \\
\hline
\end{tabular}

${ }^{a} \mathrm{Cg}(3)$ and $\mathrm{Cg}(4)$ denote centroids of the pyridyl and phenyl rings, respectively.

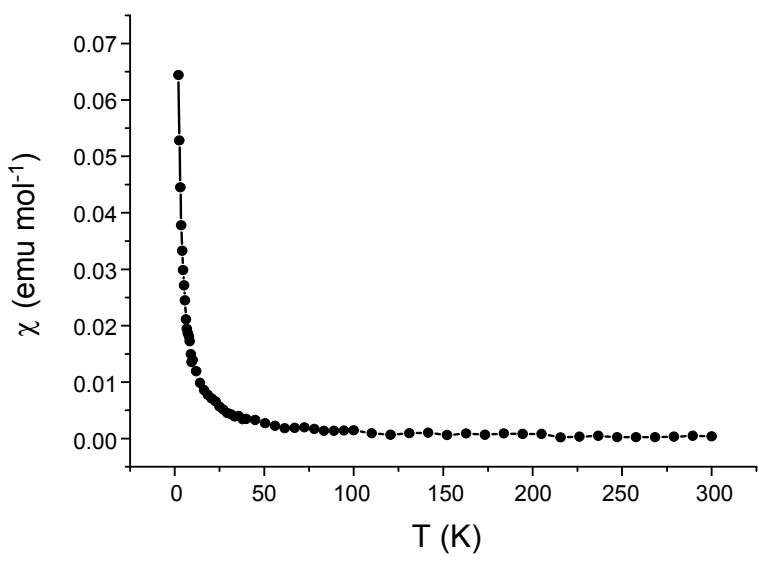

Figure 3. Temperature dependence of $\chi_{\mathrm{m}}$ for the title complex.

$-0.22 \mathrm{~K}$, respectively. This behaviour suggests that a very weak antiferromagnetic interaction operate in the title complex. ${ }^{28}$ The sample has effective magnetic moment $\mu_{\text {eff }}$ values of $0.9617 \mu_{\mathrm{B}}$ and $1.019 \mu_{\mathrm{B}}$ at 300.0 and $2.0 \mathrm{~K}$, respectively, which is lower than the spin-only value for independent $\mathrm{Cu}^{2+}$ ion $\left(\mathrm{S}=1 / 2, \mu_{\mathrm{eff}}=\right.$ $\left.1.73 \mu_{\mathrm{B}}\right)$.

Thermal stability. The TG/DTG curves of the title complex are presented in Figure 4. As seen in Figure 4, the $\left[\mathrm{Cu}_{2}\right.$ (aceace) ${ }_{4}$ (dipyph)] undergoes two-step decomposition process and there are two endothermal peaks, one is at $228.1{ }^{\circ} \mathrm{C}$ and another is at $306.9^{\circ} \mathrm{C}$. The first step of weight loss $(48.68 \%)$ occurs from 140 ${ }^{\circ} \mathrm{C}$ to $240{ }^{\circ} \mathrm{C}$, which is approximately corresponding to the cleavage of two $\mathrm{Cu}-\mathrm{N}$ bonds and two $\mathrm{Cu}-\mathrm{O}$ bonds and the loss of one dipyph ligand and one acetylacetone ligand (calcd. 47.40\%). Then, from 260 to $800{ }^{\circ} \mathrm{C}$, the title complex takes place the second-time decompose and loses weight $26.10 \%$, which is attributed to the breaking of another two $\mathrm{Cu}-\mathrm{O}$ bonds and four $\mathrm{C}=\mathrm{O}$ bonds and the loss of one acetylacetone ligand and two $\mathrm{CH}_{3} \mathrm{CCHCCH}_{3}$ groups of two acetylacetone ligands except four $\mathrm{O}$ atoms (calcd. 28.83\%). The final $25.22 \%$ residues are $\mathrm{Cu}_{2} \mathrm{O}_{4}$ (calcd. 23.76\%).

Electrochemistry. The cyclic voltammetry behaviour of the title complex was studied and the results are shown in Figure 5. For the deoxygenated experiments, the electrolyte was bubbled

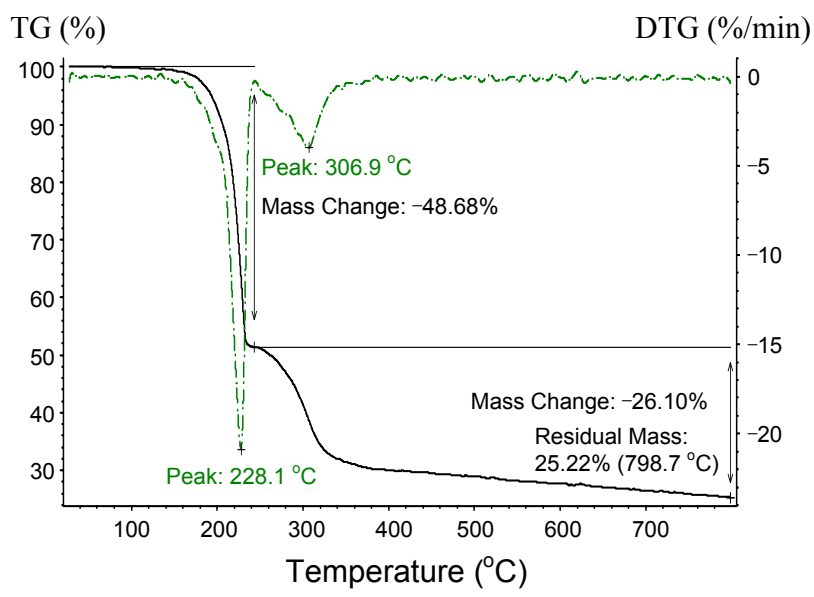

Figure 4. TG/DTG curves of the title complex. 


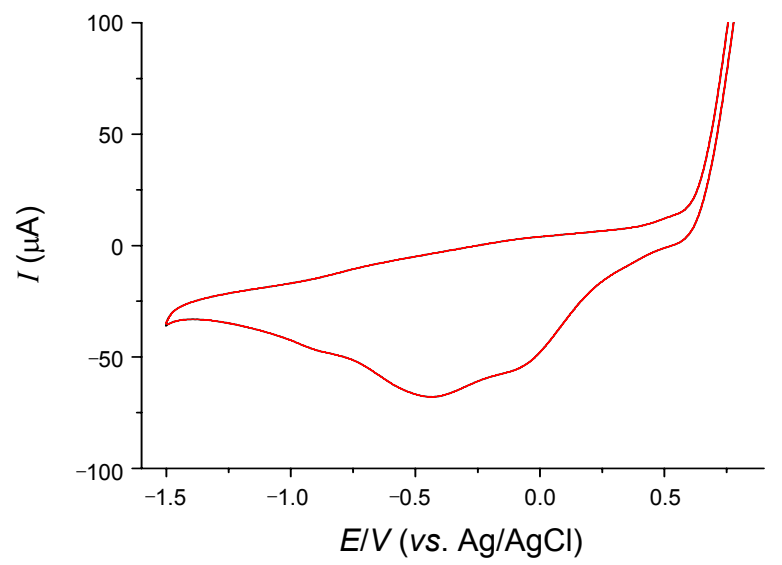

Figure 5. Cyclic voltammogram of the title complex in DMF (0.1 $\left.\mathrm{mol} \cdot \mathrm{L}^{-1} \mathrm{TBAP}\right)$.

with purity nitrogen for 10 min and maintained nitrogen condition during the experiments. As seen from Figure 5, there are two cathodic peaks at $-0.41 \mathrm{~V}$ and $-0.05 \mathrm{~V}$, respectively, while no oxidation is observed in the potential range of $-1.5 \mathrm{~V} \sim 0.8 \mathrm{~V}$, indicating that the electrochemical process of the title complex is irreversible.

\section{Conclusion}

Dinuclear $\mathrm{Cu}$ complex of $\left[\mathrm{Cu}_{2}(\text { aceace })_{4}(\right.$ dipyph $\left.)\right]$ has been synthesized and its structure has been obtained by X-ray single crystal diffraction. The inversion center of the title complex is overlap with the center of the phenyl ring. Each of the $\mathrm{Cu}^{2+}$ ion adopts a square pyramid geometry and coordinates with four $\mathrm{O}$ atoms and one $\mathrm{N}$ atom. The magnetic property measurement shows that the title complex obeys the Curie-Weiss law and there exists a very weak antiferromagnetic interaction in the title complex. Thermal stability data reveal that the title complex carried out two-step decomposition process. Electrochemical determination presents an irreversible behaviour of the title complex.

Acknowledgments. This work was supported by Doctor Foundation of Shandong Province, P. R. China (No. BS2010CL021).

Supporting Information Available. Supporting Information are available on request from the correspondence author (fax: +8653284022948 email:zhaopusu@163.com).

\section{References}

1. Consiglio, G.; Failla, S.; Finocchiaro, P.; Oliveri, I. P.; Purrello,
R.; Bella, S. D. Inorg. Chem. 2010, 49, 5134.

2. Yin, P. X.; Zhang, J.; Li, Z. J.; Qin, Y. Y.; Cheng, J. K.; Zhang, L.; Lin, Q. P.; Yao, Y. G. Cryst. Growth Des. 2009, 9, 4884.

3. Ghosh, A. K.; Jana, A. D.; Ghoshal, D.; Mostafa, G.; Ray Chaudhuri, N. Cryst. Growth Des. 2006, 6, 701.

4. Kubo, Y.; Kitada, Y.; Wakabayashi, R.; Kishida, T.; Ayabe, M.; Kaneko, K.; Takeuchi, M.; Shinkai, S. Angew. Chem. Int. Ed. 2006, 45,1548

5. Manna, S. C.; Zangrando, E.; Chaudhuri, N. R. J. Mol. Struc. 2008, $877,145$.

6. Aakeröy, C. B.; Scott, B. M. T.; Smith, M. M.; Urbina, J. F.; Desper, J. Inorg. Chem. 2009, 48, 4052.

7. Lipstman, S.; Goldberg, I. Cryst. Growth Des. 2010, 10, 1823.

8. Felloni, M.; Blake, A. J.; Hubberstey, P.; Wilson, C.; Schröder, M. Cryst. Growth Des. 2009, 9, 4685.

9. Seaton, C. C.; Parkin, A.; Wilson, C. C.; Blagden, N. Cryst. Growth Des. 2009, 9, 47.

10. Zhang, J. P.; Lin, Y. Y.; Huang, X. C.; Chen, X. M. Cryst. Growth Des. 2006, 6, 519.

11. Liang, X. Q.; Zhou, X. H.; Chen, C.; Xiao, H. P.; Li,Y.Z.; Zuo, J. L.; You, X. Z. Cryst. Growth Des. 2009, 9, 1041.

12. Manna, S. C.; Ribas, J.; Zangrando, E.; Ray Chaudhuri, N. Inorg. Chim. Acta 2007, 360, 2589.

13. Ma, M. L.; Li, X. Y.; Wen, K. J. Am. Chem. Soc. 2009, 131, 6733.

14. Zhao, S. L; Arachchige, S. M.; Slebodnick, C.; Brewer, K. J. Inorg. Chem. 2008, 47, 6144.

15. Denning, M. S.; Irwin, M.; Goicoechea, J. M. Inorg. Chem. 2008, 47, 6118 .

16. Zeng, M. H.; Zou, H. H.; Hu, S.; Zhou, Y. L.; Du, M.; Sun, H. L. Cryst. Growth Des. 2009, 9, 4239.

17. Cui, S. X.; Zhao, Y. L.; Zhang, J. P.; Liu, Q.; Zhang, Y. Cryst. Growth Des. 2008, 8, 3803.

18. Bart, S. C.; Lobkovsky, E.; Bill, E.; Wieghardt, K.; Chirik, P. J. Inorg. Chem. 2007, 46, 7055.

19. Fielden, J.; Sprott, J.; Long, D. L.; Kolgerler, P.; Cronin, L. Inorg. Chem. 2006, 45, 2886.

20. McClard, R. W.; Holets, E. A.; MacKinnon, A. L.; Witte, J. F. Biochem. 2006, 45, 5330.

21. Alessi, M.; Larkin, A. L.; Ogilvie, K. A.; Green, L A.; Lai, S.; Lopez, S.; Snieckus, V. J. Org. Chem. 2007, 72, 1588.

22. Sun, X. H.; Li, W.; Xia, P. F.; Luo, H. B.; Wei, Y.; Wong, M. S.; Cheng, Y. K.; Shuang, S. J. Org. Chem. 2007, 72, 2419.

23. SMART and SAINT for Windows NT Software Reference Mannuals, Version 5.0, Bruker Analytical X-Ray Systems, Madison, WI, 1997.

24. Sheldrick, G. M. SADABS-A Software for Empirical Absorption Correction; University of Göttingen: Göttingen, Germary, 1997.

25. SHELXTL Reference Manual, Version 5.1, Bruker Analytical X-Ray Systems, Madison, WI, 1997.

26. Atienza, J.; Gutierrez, A.; Perpinan, M. F.; Sanchez, A. E. Eur.J. Inorg. Chem. 2008, 5524.

27. Delgado, S.; Medina, M. E.; Pastor, C. J.; Jimenez-Aparicio, R.; Priego, J. L. Z. Anorg. Allg. Chem. 2007, 633, 1860.

28. Jian, F. F.; Xiao, H. L.; Wang, H. X.; Zhao, P. S.; Lu, L. D. Chin. J. Inorg. Chem. 2005, 21, 369. 